\section{Detectability of Middle Mesial Canal in Mandibular Molar After Troughing Using Ultrasonics and Magnification: An Ex Vivo Study}

Ana Carla Prade ${ }^{1}\left[\mathbb{D}\right.$, Renata Da Trindade Mostardeiro ${ }^{1}[0$, Camilla dos Santos Tibúrcio-Machado ${ }^{2}$ (으, , Renata Dornelles Morgental ${ }^{1,2}[0$, Carlos Alexandre Souza Bier ${ }^{1,2}$ [C

\author{
'Department of Stomatology, UFSM \\ - Universidade Federal de Santa \\ Maria, Santa Maria, RS, Brazil \\ ${ }^{2}$ Graduate Program in Dental Science, \\ UFSM - Universidade Federal de \\ Santa Maria, Santa Maria, RS, Brazil \\ Correspondence: Camilla dos Santos \\ Tibúrcio Machado, Rua Floriano \\ Peixoto, 1184, 97015372 Santa Maria, \\ RS, Brasil. Tel: +55-55-3220-9210. \\ e-mail: camilla_tiburcio@hotmail.com
}

\begin{abstract}
The aim of this study was to evaluate the frequency of the identification of middle mesial (MM) canals in extracted permanent first and second mandibular molars before and after executing a troughing technique with high magnification. Sample consisted of 105 mandibular molars. After gaining access to the pulp chamber and cleaning the chamber floor, root canals were detected in three different stages. The initial location was performed under direct viewing without magnification. In the second stage, a dental operating microscope was employed at 12 magnification. If the MM canal was not observed, a standardized troughing technique was executed with the use of an ultrasonic tip between the mesiobuccal and mesiolingual canals under magnification. Statistical differences in the frequency of MM canals before and after troughing were determined using McNemar's test, with the significance level set at 5\%. No significant increase in the identification of the MM canal was found when comparing observations before $(9.52 \%)$ and after $(12.38 \%)$ the troughing technique under high magnification. However, viewing under magnification and the execution of troughing significantly increased the location of the MM canal (12.38\%) when compared to viewing without magnification $(3.81 \%)(p<0.01)$. The troughing technique with the aid of a dental operating microscope significantly improved the identification of MM canals compared to viewing without magnification. Troughing is a safe, minimally invasive procedure that benefits the treatment of mandibular molars.
\end{abstract}

Key Words: accessory canal, middle mesial canal, ultrasound.

\section{Introduction}

Knowledge regarding the root canal anatomy is one of the most important aspects of achieving successful endodontic treatment (1). However, understanding all the particularities of the root canal system is a real challenge due to the highly complex internal morphology of human teeth (2-4).

Mandibular molars usually have three root canals: one distal and two mesial (mesiobuccal [MB] and mesiolingual $[\mathrm{ML}])$ canals $(2,3,5)$. However, this group of teeth exhibits considerable anatomic diversity and can have two canals in the distal root or, less often, three or four canals (6). A third canal in the mesial root, denominated middle-mesial (MM) canal $(5,7,8)$ or mesio-central canal $(9)$, may also be found. Prevalence of MM canals is associated with ethnicity (8) and age $(10,11)$. Moreover, the method employed to identify a third mesial canal exerts an influence on the detection rate, which ranges from 1 to $46 \%(2,11)$. Micro computed tomography (micro-CT) is a useful tool to study root canal morphology and it is an accurate and contemporary method of detecting MM canals (8). Unfortunately, micro-CT is not available in the clinical practice yet (12).
Notwithstanding this limitation of micro-CT, new technologies have increased the chances of locating MM canals in clinical situations. Nosrat et al. (10) found a high frequency of negotiable MM canals (20\%) using a dental operating microscope. Troughing is another strategy commonly used to locate accessory canals (13), which consists of minimal dentin removal between $\mathrm{MB}$ and $\mathrm{ML}$ canals of mandibular molars to provide better viewing of root canal orifices. The dentin removal can be done safely by using either low-speed burs or ultrasonic tips, $(11,13,14)$ avoiding the furcation area and at the expenses of the mesial wall (11). The troughing approach has been demonstrated to lead to a significant improvement in the detection of MM canals (11). Therefore, the aim of this ex vivo study was to assess the identification of MM canals before and after executing a troughing technique under high magnification.

\section{Material and Methods}

Ethical Issues and Sample Selection

This study received approval from the human research ethics committee of the Universidade Federal de Santa 
Maria (UFSM) (certificate number: 53739815.3.0000.5346). Sample comprised 105 extracted permanent mandibular first and second molars that had not previously undergone any endodontic intervention. Specimens were donated by the Human Permanent Tooth Bank of the university. Patient's sex and age were unknown.

Teeth were submitted to cleaning for the removal of carious tissue and dental calculus, followed by a 30-minute sterilization cycle at $121^{\circ} \mathrm{C}$. Roots were then embedded in silicone impression material (Zhermack, Badia Polesine, RO, Italy) up to the cement-enamel junction.

\section{Access to Pulp Chamber, Shaping, And Cleaning of Chamber Floor}

Access cavity was prepared with a 1015 spherical diamond tip (KG Sorensen, São Paulo, Brazil), followed by an Endo-Z bur (Microdont, São Paulo, Brazil) coupled to a high-speed handpiece (Kavo, São Paulo, Brazil) with constant irrigation. Pulp chamber floor was cleaned with a G6-S ultrasonic tip (Schuster, Rio Grande do Sul, Brazil) at 50\% power, using the Soniclaxis BP ultrasound system (Schuster, Rio Grande do Sul, Brazil). The procedure was performed with a minimal flow of distilled water (Asfer, ¿ São Paulo, Brazil).

\section{Localization of Root Canals}

Two independent operators performed the localization of root canals after undergoing a training process for the execution of the clinical procedures. Location of MM canals was performed in three different stages.

Stage 1 (direct viewing): Root canals of the mesial root were first located using an endodontic explorer (Golgran, São Paulo, Brazil) with direct viewing and no magnification. A size $10 \mathrm{~K}$-file (Kendo, Munich, Germany) was inserted in each canal orifice to confirm the presence of the MM canal.

Stage 2 (viewing with microscope prior to troughing): A dental operating microscope (DM 2003 model, OPTO Eletrônica S/A, São Paulo, Brazil) at $\times 12$ magnification was used at this stage in the teeth that did not show the MM canal at stage 1.

Stage 3 (viewing with microscope after troughing): If the $\mathrm{MM}$ was still not located, a guided troughing technique was performed between the MB and ML canals. The troughing technique was executed as previously described $(11,13)$, with minor adaptations. Dentin removal was achieved using a TRA15 CD ultrasonic tip (Trinks, São Paulo, SP, Brazil) coupled to the ultrasound device with $80 \%$ power under irrigation. A reference point was drawn on the tip to ensure a troughing depth of $2 \mathrm{~mm}$ (Fig. 1A). After the procedure, the final evaluation of the canals was performed with the aid of an optical microscope ( $\times 12$ magnification), endodontic explorer and size $10 \mathrm{~K}$-file (Fig. 1B).
After locating the MM canal, a radiograph was taken with size $10 \mathrm{~K}$-files inserted in all canals found to determine the presence of the MM canal (Fig. 1C). To be considered present, the MM canal needed to be negotiable up to 5 $\mathrm{mm}$ from the radiographic apex (11).

\section{Statistical Analysis}

Kappa statistic was used to determine inter-examiner agreement ( $k=0.79$ ). Divergences of opinion were discussed until reaching a consensus. The number and frequency of MM canals detected were calculated for the three stages. McNemar's test was used to determine significant differences regarding the identification of MM canals among the three stages. Chi-square test was used to determine differences in the identification of MM canals between the first and second molars. Stata 12.0 program (Stata Corp LP, Texas, USA) was used for all statistical analyses, with level of significance set at $5 \%(p<0.05)$.

\section{Results}

First molars accounted for $50.48 \%$ of the sample and second molars accounted for $49.52 \%(n=105)$. The execution of troughing did not significantly increase the detection of MM canals compared to viewing with a microscope prior to troughing. However, viewing with a microscope and troughing significantly increased the localization of the MM canal compared to viewing without magnification (Table 1). Although the frequency of MM canals was greater in second molars than first molars, this difference did not achieve statistical significance (Table 2).

\section{Discussion}

The present results suggest no significant difference in locating the middle-mesial canal before and after troughing when magnification is used with a dental operating microscope. However, magnification significantly increased the localization of these canals in comparison to direct viewing without magnification.

The sample in the present study was homogeneous with regard to the type of tooth evaluated. Among the 105 mandibular specimens, 50.48\% were first molars and $49.52 \%$ were second molars, enabling the evaluation of whether the prevalence of MM canals is associated with the type of molar examined. The findings reveal that, despite the greater identification of MM canals in mandibular second molars, the difference was not statistically significant, which is in agreement with data described by Karapinar-Kazandag et al. (15) and Azim et al. (11). In contrast, Carvalho and Zuolo (16) stated that MM canals are more prevalent among first molars than second molars. However, the findings of an in vivo study make it evident that the type of molar is not a determinant factor for a 
greater prevalence of a third canal in the mesial root (10). Progressive calcification of the pulp space may be the reason why $\mathrm{MM}$ canals were more prevalent in second molars in the present investigation, despite the lack of statistical significance. As second molars erupt later, it is more likely for MM canals to be located in these teeth, since first molars have a longer period of time to undergo

Table 1. Identification of MM canals in different stages of the study $(\mathrm{n}=105)$

\begin{tabular}{lcc}
\hline Stage & $\mathrm{n}(\%)$ & $\mathrm{p}$ value \\
\hline Direct viewing & $4(3.81 \%)$ & $0.01^{*} /<0.01^{* *}$ \\
$\begin{array}{l}\text { Viewing with microscope } \\
\text { prior to troughing }\end{array}$ & $10(9.52 \%)$ & \\
$\begin{array}{l}\text { Viewing with microscope } \\
\text { after troughing }\end{array}$ & $13(12.38 \%)$ & $>0.05^{* * * *}$ \\
\hline
\end{tabular}

*comparing direct viewing to microscope prior to troughing. *** comparing direct viewing to microscope after troughing. ****omparing viewing with microscope before and after troughing McNemar's test. compression and calcification (17).

Patients' age is one of the variables that exert an influence on the localization of MM canals $(10,11,18)$. Nosrat et al. (10) found a statistically significant difference in the occurrence of this canal in different age groups, with a $32.1 \%$ prevalence rate among 21 -year-old patients and $3.8 \%$ among those older than 40 years of age. This may be explained by the calcification process of the pulp

Table 2. Identification of MM canals according to the type of molar $(n=105)$

\begin{tabular}{lcc}
\hline Variable & $\begin{array}{c}\text { Prevalence of } \\
\text { MM canal n (\%) }\end{array}$ & p value \\
\hline Type of molar & & $>0.05$ \\
Mandibular first molar & $4(7.55 \%)$ & \\
Mandibular second molar & $9(17.31 \%)$ & \\
\hline
\end{tabular}

Chi-square test.
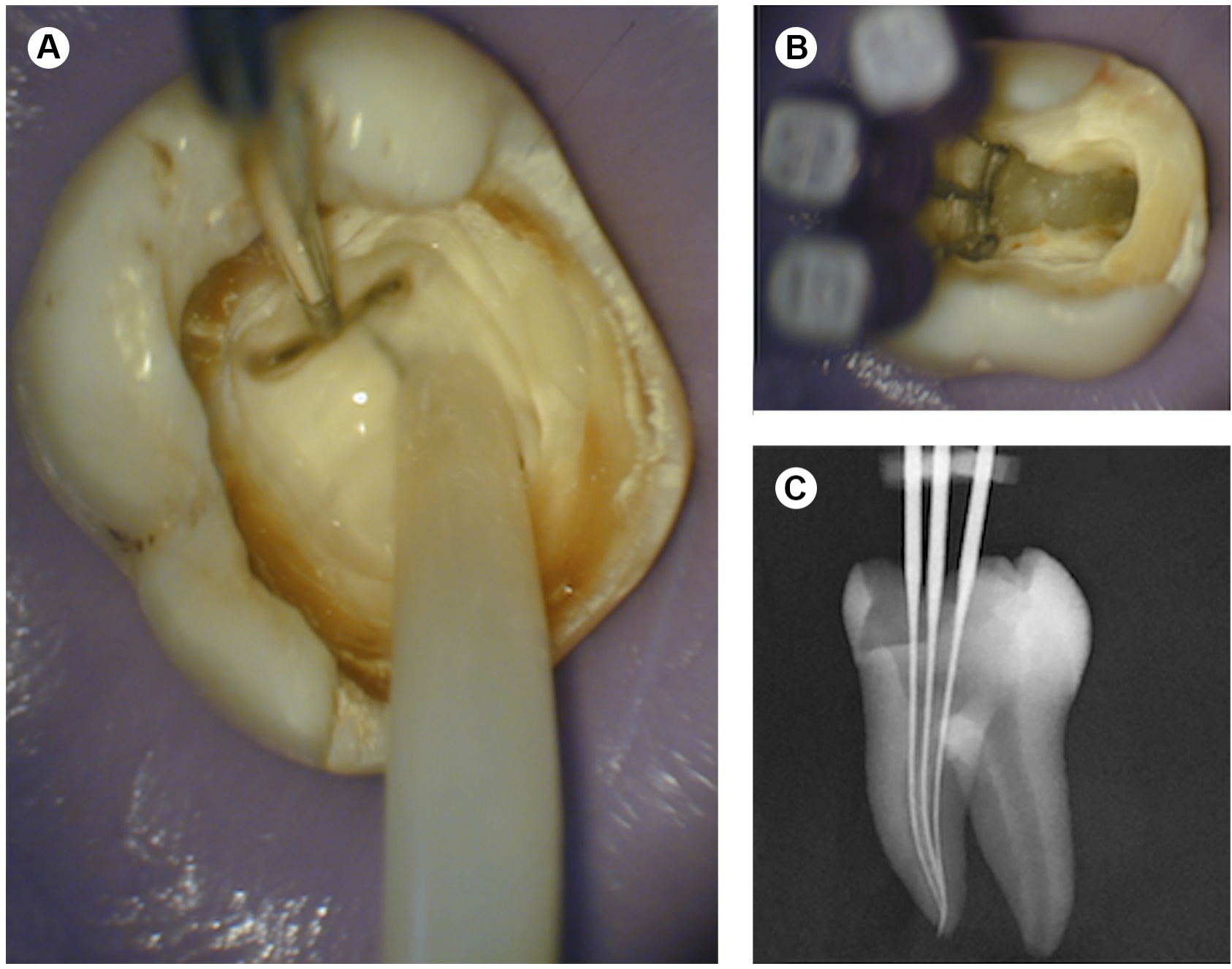

Figure 1. Troughing technique (A); MM canal identified after troughing (B); Radiography confirming identification of MM canal (C). 
chamber and root canals, which undergo a reduction in size due to the continuous deposition of dentin over the years (17). In the present study, it was not possible to associate the presence of MM canals with patients' age due to the characteristics of the sample, since this information was not available.

The guided troughing technique may increase the chances of locating MM canals in mandibular molars (11). This method consists of creating a depression in the dentin between the MB and ML canals, which can be performed with low-speed spherical burs or ultrasound equipment. In an in vivo study, Azim et al. (11) used spherical burs to create a $2 \mathrm{~mm}$ trough between the main canals under magnification with a dental microscope. Ultrasound was used in the present investigation, in a similar manner as that described by Yoshioka et al. (13) in maxillary molars. Ultrasound provides more cautious dentin removal, ensuring greater safety and control (19).

Although no statistically significant difference was found in the frequency of the localization of MM canals before and after the troughing technique, the use of the technique increased the identification by nearly $3 \%$ in comparison to viewing with the optical microscope prior to $\dot{s}$ troughing. This justifies the practice, as the trough created in dental structure is minimal and chances of locating an MM canal are greater. According to results of a recent study using micro-CT, the depth of MM canals is $1 \mathrm{~mm}$ from the cement-enamel junction in 5.38\% of the cases and $2 \mathrm{~mm}$ in $9.69 \%$ of cases, while the majority $(77.41 \%)$ is located on the level of the cement-enamel junction (20). This may explain why an improvement in locating MM canals occurred using magnification even without performing the troughing technique.

Indeed, the use of the optical microscope proved to be efficient at detecting MM canals, even without having performed the troughing approach, with a detection rate of 9.52\% compared to only $3.81 \%$ using the direct viewing technique. Karapinar-Kazandag et al. (15) found a $4 \%$ increase in the detection of accessory mesial canals in mandibular molars after exploration under optical microscopy. Likewise, Carvalho and Zuolo (16) found an 8.6 and $2.33 \%$ increase in the detection of MM canals in mandibular first and second molars, respectively, using high magnification.

The configuration of root canal systems in mandibular molars is very complex, especially in the mesial root. Due to its considerable buccolingual width, it is common to find intercanal connections and isthmuses, which, according to a systematic review (21), are present in $54.8 \%$ of mandibular first molars. Micro-CT technology has confirmed the high complexity of this system (22). After scanning 258 mandibular molars from Brazilian and Turkish individuals,
Versiani et al. (8) found that few samples (6.3\%) of the 48 teeth with MM canals had three separate canals. The vast majority had a confluent configuration (83.3\%), in which MB and ML canals interconnect by an isthmus, transverse anastamosis, and intercanal connections at some point of the trajectory.

A limitation of the present study is that the proposed methodology cannot provide precise information on the configuration of mesial canals and the possible connection between them at different root levels. However, although $M B, M M$, and ML canals may have interconnections, the best clinical approach is to treat them as independent canals. Paqué et al. (23) assessed untouched areas in oval-shaped canals provided by different instrumentation techniques; all samples showed unprepared areas, but considering the root canal as two distinct canals provided the best preparation technique with regard to dentin removal.

Within the limitations of an ex vivo study, the present findings demonstrate that, although a larger number of MM canals were located after executing the troughing technique, the difference did not achieve statistical significance. However, the identification of MM canals was significantly higher when a dental operating microscope was used for magnification in comparison to direct observation. Yet, troughing is justifiable due to the fact that it is a minimally invasive technique that assists in the detection of MM canals when combined with the use of dental operating microscope.

\section{Resumo}

0 objetivo deste estudo foi avaliar a frequência de identificação do canal médio-mesial (MM) antes e após a execução da técnica de troughing sob ampliação microscópica em primeiros e segundos molares inferiores permanentes extraidos. A amostra foi composta por 105 molares inferiores. Após abertura coronária e limpeza do assoalho pulpar, os canais radiculares foram detectados em três etapas diferentes. A localização inicial foi realizada sob visão direta, sem ampliação microscópica. Na segunda visualização, foi empregado um microscópio óptico com um aumento de $\times 12$. Se o canal MM não foi observado, uma técnica padronizada de troughing foi realizada com o uso de pontas ultrassônicas entre os canais mésio-vestibular e mésio-lingual sob ampliação microscópica. Diferenças estatísticas na frequência dos canais MM antes e após o troughing foram determinadas usando o teste de McNemar, com um nivel de significância de $5 \%$. Não houve um aumento estatisticamente significativo na identificação do canal MM quando comparadas as visualizações antes $(9,52 \%)$ e depois $(12,38 \%)$ da técnica do troughing utilizando o microscópio óptico. Porém, a visualização com microscópio e a execução do troughing aumentaram significativamente a localização do canal $\mathrm{MM}(12,38 \%)$ quando comparada à visão prévia sem aumento $(3,81 \%)(\mathrm{p}<0,01)$. A técnica do troughing com o auxilio do microscópio óptico aumentou significativamente a identificação do canal $\mathrm{MM}$ quando comparada à visualização sem magnificação. Troughing é um técnica segura, minimamente invasiva e traz benefícios ao tratamento de molares inferiores.

\section{References}

1. Slowey RR. Root canal anatomy. Road map to successful endodontics. 
Dent Clin North Am 1979;23:555-573.

2. Vertucci FJ. Root canal anatomy of the human permanent teeth. Oral Surg Oral Med Oral Pathol 1984;58:589-599.

3. Gulabivala $\mathrm{K}$, Aung TH, Alavi A, Ng YL. Root and canal morphology of Burmese mandibular molars. Int Endod J 2001;34:359-370.

4. Briseño-Marroquín B, Paqué F, Maier K, Willershausen B, Wolf TG. Root canal morphology and configuration of 179 maxillary first molars by means of micro-computed tomography: an ex vivo study. J Endod 2015;41:2008-2013.

5. Barker BC, Parsons KC, Mills PR, Williams GL. Anatomy of root canals. III. Permanent mandibular molars. Aust Dent J 1974;19:408-413.

6. Filpo-Perez C, Bramante CM, Villas-Boas MH, Duarte MAH, Versiani MA Ordinola-Zapata R. Micro-computed tomographic analysis of the root canal morphology of the distal root of mandibular first molar. J Endod 2015;41:231-236.

7. Vertucci FJ, Williams RG. Root canal anatomy of the mandibular first molar. J N J Dent Assoc 1974;45:27-28.

8. Versiani MA, Ordinola-Zapata R, Keleş A, Alcin H, Bramante CM, Pécora JD, et al. Middle mesial canals in mandibular first molars: A micro-CT study in different populations. Arch Oral Biol 2016;61:130-137.

9. Vande Voorde HE, OdendahI D, Davis J. Molar 4th canals: frequent cause of endodontic failure? III Dent J 1975;44:779-786.

10. Nosrat A, Deschenes RJ, Tordik PA, Hicks ML, Fouad AF. Middle mesial canals in mandibular molars: incidence and related factors. J Endod 2015;41:28-32.

11. Azim AA, Deutsch AS, Solomon CS. Prevalence of middle mesial canals in mandibular molars after guided troughing under high magnification: an in vivo investigation. J Endod 2015;41:164-168.

12. Anderson PJ, Yong R, Surman TL, Rajion ZA, Ranjitkar S. Application of three-dimensional computed tomography in craniofacial clinical practice and research. Aust Dent J 2014;59:174-185.

13. Yoshioka T, Kikuchi I, Fukumoto Y, Kobayashi C, Suda H. Detection of the second mesiobuccal canal in mesiobuccal roots of maxillary molar teeth ex vivo. Int Endod J 2005;38:124-128.
14. Gorduysus MO, Gorduysus M, Friedman S. Operating microscope improves negotiation of second mesiobuccal canals in maxillary molars. J Endod 2001;27:683-686.

15. Karapinar-Kazandag M, Basrani BR, Friedman S. The operating microscope enhances detection and negotiation of accessory mesial canals in mandibular molars. J Endod 2010;36:1289-1294.

16. de Carvalho MC, Zuolo ML. Orifice locating with a microscope. J Endod 2000;26:532-534.

17. Philippas GG. Influence of Occlusal Wear and Age on Formation of Dentin and Size of Pulp Chamber. J Dent Res 1961;40:1186-1198.

18. Akbarzadeh N, Aminoshariae A, Khalighinejad N, Palomo JM, Syed A, Kulild JC, et al. The association between the anatomic landmarks of the pulp chamber floor and the prevalence of middle mesial canals in mandibular first molars: an in vivo analysis. J Endod 2017.

19. Plotino G, Pameijer CH, Maria GN, Somma F. Ultrasonics in Endodontics: A Review of the Literature. J Endod 2007;33:81-95.

20. Keleş A, Keskin C. Detectability of middle mesial root canal orifices by troughing technique in mandibular molars: a micro-computed tomographic study. J Endod 2017;43:1329-1331.

21. De Pablo ÓV, Estevez R, Péix SM, Heilborn C, Cohenca N. Root anatomy and canal configuration of the permanent mandibular first molar: $\mathrm{A}$ systematic review. J Endod 2010;36:1919-1931.

22. Wolf TG, Paqué $F$, Zeller M, Willershausen B, Briseño-Marroquín B. Root canal morphology and configuration of 118 mandibular first molars by means of micro-computed tomography: an ex vivo study. J Endod 2016;42:610-614.

23. Paqué $F$, Balmer $M$, Attin T, Peters OA. Preparation of oval-shaped root canals in mandibular molars using nickel-titanium rotary instruments: a micro-computed tomography study. J Endod 2010;36:703-707.

Received May 9, 2018 Accepted October 3, 2018 